\title{
THE DEVELOPMENT OF FERRITIC STEELS FOR FAST INDUCED-RADIOACTIVITY DECAY FOR FUSION REACTOR APPLICATIONS *
}

\author{
R.L. KLUEH and E.E. BLOOM \\ Metals and Ceramics Division, Oak Ridge National Laboratory, Oak Ridge, TN 37831, USA
}

Received 21 April 1984

\begin{abstract}
The $\mathbf{C r}$-Mo ferritic (martensitic) steels are leading candidates for the structural components for future fusion reactors. However, irradiation of such steels in a fusion environment produces long-lived radioactive isotopes that lead to difficult waste disposal problems once the structure is removed from service. One method proposed to alleviate such problems is the development of steels that contain only elements that produce radioactive isotopes that decay to low levels in a reasonable time (tens of years instead of hundreds or thousands of years). For such a solution for the $\mathrm{Cr}-\mathrm{Mo}$ steels, molybdenum must be eliminated. In addition, niobium must be maintained at extremely low levels. Tungsten is proposed as an appropriate substitution for molybdenum, and the procedures for developing $\mathrm{Cr}-\mathrm{W}$ steels analogous to the $\mathrm{Cr}$-Mo steels are discussed.
\end{abstract}

\section{Introduction}

The most serious safety and environmental concerns for fusion reactors involve induced radioactivity in the first-wall and blanket structures. Public safety could be jeopardized by the accidental release of this induced radioactivity, and the biological hazard for plant personnel would eliminate the possibility of contact maintenance and repair. Another problem is that of special waste storage of the highly radioactive blanket and first-wall structures after service. All these problems would be alleviated by the use of a low activation structural material. However, as pointed out in a recent report by a US Department of Energy (DOE) panel set up to study this subject, the technology for commercially producing and fabricating material that would meet the low-activation criteria is not available and is unlikely to be available soon (high-purity silicon carbide was the only material suggested) [1]. Although other solutions must be sought for the safety and maintenance problems, it appears to be possible to simplify the storage of radioactive reactor components by developing a material in which the induced radioactivity decays in a reasonable time to such a level that the waste no longer requires maintenance.

* Research sponsored by the Office of Fusion Energy, US Department of Energy under contract DE-AC05-84OR21400 with the Martin Marietta Energy Systems, Inc.

\section{Radioactive waste and storage guidelines}

Guidelines (10 CFR Part 61) for the classification and disposal of low-level nuclear wastes have been issued by the US Nuclear Regulatory Commission [2]; these guidelines are summarized in table 1 . The DOE Panel on Low Activation Materials set as a goal the development of reactor materials that fall within Class C, but with the hope to meet Class B criteria [1]. It should be noted that the 10 CFR Part 61 guidelines were developed primarily to treat fission reactor waste and will undoubtedly be extensively revised by the time the first components are discharged from an operating fusion reactor and are ready for disposal. Nevertheless, these guidelines offer a standard to which alloys can be developed for eventual inexpensive near-surface disposal.

The 10 CFR Part 61 guidelines were examined by the DOE panel [1]. On the basis of the guidelines, initial concentration limits were calculated for various common alloying elements for the three waste classes for first-wall and blanket structures ten years after the shutdown of a reactor given a $9 \mathrm{MW} \cdot \mathrm{yr} / \mathrm{m}^{2}$ exposure. The limits are given in table 2 . Based on the possibility that a material resulting in Class $A$ waste is quite remote (e.g., impurity-free silicon carbide), vanadium alloys (alloyed with chromium and titanium) offer the possibility for Class B waste (residual impurities would appear to make Class $A$ vanadium alloys impossible). It

0167-899x/85/\$03.30 을 Elsevier Science Publishers B.V. (North-Holland Physics Publishing Division) 
Table 1

Nuclear waste classification and storage under proposed 10 CFR Part 61 rules

\begin{tabular}{lll}
\hline Waste class & Definition & Disposal \\
\hline $\begin{array}{l}\text { Class A, segregated } \\
\text { Class B, stable }\end{array}$ & $\begin{array}{l}\text { Decays to acceptable levels during site occupancy } \\
\text { Decays within 100 years to levels not dangerous to } \\
\text { public health and safety }\end{array}$ & $\begin{array}{l}\text { Covered to reduce surface radiation } \\
\text { to a few percent of background }\end{array}$ \\
Class C, intruder & $\begin{array}{l}\text { Decays to acceptably safe levels in more than } \\
\text { At least } 5 \mathrm{~m} \text { below the surface, with }\end{array}$ \\
$\begin{array}{l}\text { Waste not meeting } \\
\text { Class C intruder }\end{array}$ & Decays in more than 500 years & $\begin{array}{l}\text { natural or engineered barriers } \\
\text { waste definition }\end{array}$ \\
\end{tabular}

appears that steels will have to be handled as Class $\mathrm{C}$ waste [1].

Table 2 shows that, for the induced radioactivity of a steel to decay rapidly enough to qualify for Class $C$ treatment, certain common steel alloying elements must be restricted. In particular, niobium must be eliminated (it is the restriction on niobium that will probably make it impossible ever to meet the Class B criteria for any steel). Concentrations of $\mathrm{Ni}, \mathrm{Mo}$, and $\mathrm{N}$ must be severely restricted in the steels being considered for first-wall and blanket structure applications. Copper, generally present as an impurity, will also have to be controlled.

In this paper, the development of steels with "fast" induced-radio-activity decay (FIRD) characteristics are discussed. Fast is a relative term, which for this discussion is taken to mean steels with radioactive decay rapid enough to qualify at least for Class $\mathrm{C}$ waste disposal criteria. The term low activation material is often used to describe alloys that minimize waste disposal and those that would allow hands-on maintenance. Materials that would allow hands-on maintenance would not only have to have low activation, but would also have to decay to extremely low levels very rapidly (e.g., pure $\mathrm{SiC}$ ).

The DOE panel called attention to the difficulty of defining low activation materials by defining four types of fusion reactors and materials [1]. It defined standard activation, very low activation, low activation, and reference activation reactors and materials.

A standard activation reactor would be constructed of a standard activation material such as type 316 stainless steel or $12 \mathrm{Cr}-1 \mathrm{MoVW}$ steel, which does not meet the criteria for shallow land burial of the radioactive waste after reactor shutdown. For such reactors, all maintenance must be performed remotely.

A very low activation reactor would be constructed from a very low activation material that would be disposable according to the Class A criteria of 10 CFR

Table 2

Initial concentration level restrictions from 10 CFR Part 61 waste disposal rules ten years after shutdown, $9 \mathrm{MW} \cdot \mathrm{yr} / \mathrm{m}^{2}$ exposure (from ref. [1])

\begin{tabular}{|c|c|c|c|}
\hline \multirow[t]{2}{*}{ Element } & \multicolumn{3}{|c|}{$\begin{array}{l}\text { Initial concentration limit } \\
\text { (at. ppm) }\end{array}$} \\
\hline & Class A & Class B & Class C \\
\hline $\mathrm{O}$ & 250000 & $-b$ & $10^{6}$ \\
\hline Co & 30 & $10^{6}$ & $10^{6}$ \\
\hline $\mathrm{Cu}$ & 12 & 240 & 2400 \\
\hline $\mathrm{Ni}$ & 100 & 2000 & $20^{\prime} 000$ \\
\hline Mo & 365 & $-{ }^{b}$ & 3650 \\
\hline $\mathrm{Mn}$ & 5000 & $10^{6}$ & $10^{6}$ \\
\hline $\mathrm{Nb}$ & 0.1 & $-\mathbf{b}$ & 1 \\
\hline $\mathrm{Al}, \mathrm{C}, \mathrm{Mg}, \mathrm{Si}, \mathrm{Ti}, \mathrm{V}$ & $10^{6}$ & $10^{6}$ & $10^{6}$ \\
\hline
\end{tabular}

a Limits apply to first-wall region.

b Storage in this classification is not defined. 
Part 61 and would allow limited hands-on maintenance behind the blanket within $2 \mathrm{~d}$ of shutdown.

The low activation reactor would be constructed of materials that met the Class $B$ criteria, and hands-on maintenance would be possible outside the blanket or outside the shield within $2 \mathrm{~d}$ of shutdown.

Finally, a reference activation reactor would be constructed of a reference activation material that met Class C criteria; such a material would allow limited hands-on maintenance outside the shield within $2 \mathrm{~d}$ of shutdown. The FIRD steels to be discussed here fall into the class of reference activation materials.

The limits on the initial concentrations of $\mathrm{Ni}$, Mo, $\mathrm{Cu}$, and $\mathrm{N}$ (table 2) established by the 10 CFR Part 61 guidelines are mutually exclusive. That is, if any one of the elements is present at the concentration limit, the other elements must be absent. The 1 at. ppm limit for niobium will be the most difficult to meet. Because of this restrictiveness on the niobium, the alloys discussed below will be those for which $\mathrm{Mo}, \mathrm{Ni}, \mathrm{Cu}$, and $\mathrm{N}$ will be kept to a minimum.

For a various technological reasons, the austenitic stainless steels and the $\mathrm{Cr}$-Mo ferritic (and martensitic) steels are the leading candidate alloys for fusion reactor structures. The effect or irradiation on such steels has been extensively studied in both the fusion reactor and the breeder reactor development programs. Furthermore, an extensive background of experience is available to draw on for fabricating large and complicated steel structures for elevated-temperature service. Because of this background of experience with such steels, these materials are the logical choices for modification to develop FIRD alloys.

Common steel alloying elements that can be used in FIRD steels include $\mathrm{Mn}, \mathrm{Ti}, \mathrm{Cr}, \mathrm{Si}, \mathrm{W}, \mathrm{V}, \mathrm{Ta}, \mathrm{Co}$, and C. The most important of the elements not available are nickel and molybdenum. Both elements are present in austenitic stainless steels, and molybdenum is used in the $\mathbf{C r}-\mathrm{Mo}$ ferritic steels. If these two types of steels are to be used, substitutions must be found for these two elements. In a previous paper, the possibility for FIRD austenitic stainless steels similar to type 316 stainless steel and the austenitic prime candidate alloy developed in the fusion program were discussed [3]. In this paper, we will discuss the possibilities for developing FIRD ferritic steels similar to the $\mathrm{Cr}-\mathrm{Mo}$ steels.

\section{FIRD ferritic steels}

The Cr-Mo ferritic steels are of two types: (1) those that basically contain only $\mathrm{Fe}, \mathrm{Cr}, \mathrm{Mo}$, and $\mathrm{C}$ and (2) those that contain these elements plus one or more of the strong carbide formers $\mathrm{Nb}, \mathrm{V}, \mathrm{Ti}$, and $\mathrm{W}^{*}$ [4]. An example of the first type is $2 \frac{1}{4} \mathrm{Cr}-1$ Mo steel. This steel was an outgrowth of the C-Mo steels, with the chromium added to increase ductility, to decrease the tendency to graphitization, and to provide oxidation and corrosion resistance at elevated temperature. Much of the elevated-temperature strength in this alloy is provided by a dispersion of $\mathrm{Mo}_{2} \mathrm{C}$ [5]; molybdenum also provides solid-solution strengthening. Several other carbides also form [6], including $\mathrm{M}_{3} \mathrm{C}, \mathrm{M}_{7} \mathrm{C}_{3}, \mathrm{M}_{23} \mathrm{C}_{6}$, and $\mathrm{M}_{6} \mathrm{C}$. After prolonged exposure at elevated temperature, only $\mathrm{M}_{23} \mathrm{C}_{6}$ and $\mathrm{M}_{6} \mathrm{C}$ remain. The addition of $0.25 \% \mathrm{~V}$ to $2 \frac{1}{4} \mathrm{Cr}-1$ Mo steel has a pronounced effect on the precipitate formed and thus on its elevated-temperature properties [7]. In addition to the molybdenumand chromium-rich carbides, $\mathrm{V}_{4} \mathrm{C}_{3}$ appears. The fine dispersion of this precipitate provides increased creep strength.

The high-chromium $\mathrm{Cr}-\mathrm{Mo}$ steels have attracted attention for fusion reactor applications $[8,9]$. Steels with 9 or $12 \% \mathrm{Cr}$ and $1 \%$ Mo are being investigated. Without the addition of a strong carbide-forming element, $\mathrm{M}_{23} \mathrm{C}_{6}$ precipitate forms in these high-chromium steels [10]. When vanadium is added, $\mathrm{M}_{23} \mathrm{C}_{6}$ is still the predominant precipitate and the only one present at equilibrium [10]. However, the addition of vanadium leads to a finer, more stable $\mathrm{M}_{23} \mathrm{C}_{6}$, which increases the elevatedtemperature strength. Small amounts of niobium and titanium added to these steels lead to the formation of niobium- and titanium-rich MC-type carbides in addition to $M_{23} C_{6}[10,11]$. Evidently these alloying elements are not as readily absorbed in the $\mathrm{M}_{23} \mathrm{C}_{6}$ as is vanadium. The formation of a fine dispersion of these precipitates at the service temperature can lead to improved strength, although a reduced ductility can also result. A small amount of tungsten $(\sim 0.5 \mathrm{wt} \%)$ added to the high-chromium $\mathrm{Cr}-\mathrm{Mo}$ steels has a minor effect on strength, probably caused by solid-solution effects $[12,13]$.

\subsection{Alloy composition selection}

If the objective in developing a FIRD alloy is the replacement of molybdenum in the $\mathrm{Cr}-\mathrm{Mo}$ steels with an element that will lead to dispersion strengthening, vanadium would appear to be a logical choice. Just as

* These are the elements that give strength to the $\mathrm{Cr}$-Mo steels through carbide formation. The commercial steels generally also contain up to $0.5 \% \mathrm{Mn}, 0.4 \% \mathrm{Si}$, and $0.5 \mathrm{Ni}$ plus small amounts of impurities. 
the $\mathrm{Cr}$-Mo steels evolved from the Fe-Mo-C steels, which develop their strength from molybdenum carbides, a similar progression from $\mathrm{Fe}-\mathrm{V}-\mathrm{C}$ would seem to be possible. Indeed, a $2 \frac{1}{4} \mathrm{Cr}-1.5 \mathrm{~V}$ steel has been proposed as a FIRD alloy [14].

Considerable research has been conducted on Fe-V-C steels, which develop their elevated-temperature strength by the formation of $V_{4} C_{3}$ [15-17]. Two types of heat treatment have been considered for these steels. First, a conventional quench-and-temper or normalize-and-temper heat treatment can be used to form a tempered martensite that contains the $V_{4} C_{3}$. A second possibility studied in recent years is the use of a direct transformation. In this process, a ferrite that contains fine carbide precipitates and has superior properties to those of a quenched-and-tempered product can be developed. By direct transformation, which is most easily obtained by an isothermal treatment, a fine interphase precipitate of $\mathrm{V}_{4} \mathrm{C}_{3}$ is formed rather uniformly throughout the ferrite [16] (an interphase precipitate forms in conjunction with the movement of the austenite-ferrite boundary during transformation). Studies have been made to determine how an interphase precipitate could be developed in a continuous cool (as opposed to an isothermal transformation) from the austenitizing temperature - a probable necessity for a commercial steel [17]. One way to accomplish this is by adding nickel or manganese to the steel; however, nickel should be avoided for a FIRD alloy.

Because any ferritic steel developed for fusion reactor applications should have properties that allow it to be used at temperatures as high as 500 to $550^{\circ} \mathrm{C}$, and if possible to $600^{\circ} \mathrm{C}$, the alloy will undoubtedly need to contain chromium for oxidation and corrosion resistance. Little information is available, however, on the effect of chromium on the Fe-V-C steels. The major effect of chromium is the appearance of the chromiumrich carbides in the precipitation sequence. The carbides that form will depend on the vanadium and chromium concentrations; an equilibrium structure of $\mathrm{V}_{4} \mathrm{C}_{3}$ and either $M_{7} C_{3}$ or $M_{23} C_{6}$ would be expected for vanadium and chromium concentrations of probable interest $(0-1 \% \mathrm{~V}$ and $2-12 \% \mathrm{Cr}$ ) [18,19]. Chromium could also change the precipitate morphology that results during a direct transformation. Instead of a fine interphase precipitate distributed uniformly throughout the microstructure, chromium may promote the formation of a fibrous precipitate, usually consisting of carbide fibers 30 to $50 \mathrm{~nm}$ in diameter spaced about 30 to $50 \mathrm{~nm}$ apart [16]. (The precipitation sequence for such carbides appears to be similar to the process by which pearlite forms.) The effect of such a precipitate morphology on mechanical properties is not known, although the properties are not expected to be as favorable as are those of a fine interphase precipitate.

Any alloy development program should concentrate on alloys in a normalized-and-tempered or quenchedand-tempered condition (i.e., avoid the direct transformation route, because such a heat treatment would be difficult to apply commercially). If vanadium is to replace molybdenum in $\mathrm{Cr}$-Mo steels, a start should be made with 0.25 and $0.5 \mathrm{wt} \% \mathrm{~V}$ in steels with 2 to $2.5 \%$ $\mathrm{Cr}$ (less vanadium is required because the molecular weight of vanadium is about one-half that of molybdenum). Vanadium can affect the weldability of a steel, so less than $0.15 \% \mathrm{C}$ should be used; it may also be of interest to investigate the effect of carbon $(0.1$ and $0.15 \%$ alloys).

Because of the large uncertainty with regard to weldability in the development of $\mathrm{Cr}-\mathrm{V}$ steels, the $\mathrm{Cr}-\mathrm{W}$ steels may offer the best possibility for the development of a replacement for $\mathrm{Cr}$-Mo steels. Tungsten is in the same group of the periodic table and displays several similarities to molybdenum when it is used as an alloying element in steels. All indications are that $\mathrm{Fe}-\mathrm{W}-\mathrm{C}$ alloys develop analogous precipitates with similar precipitation sequences to Fe-Mo-C alloys (i.e., both form $\mathrm{M}_{2} \mathrm{C}$ and $\mathrm{M}_{6} \mathrm{C}$ of similar morphology [16]). Tungsten and molybdenum also show similar solid-solution hardening characteristics [16]. One important difference involves the diffusion of the two atoms: the tungsten diffusivity is substantially less than that of molybdenum. This results in a slower developing secondary hardening peak for a tungsten steel; however, the tungsten steel does not overage as rapidly. (Note that the secondary hardening peak for a tungsten steel is not as large as is that for a comparable molybdenum steel.) This similarity of tungsten and molybdenum suggests an initial steel composition of 2 to $2.5 \% \mathrm{Cr}-2 \% \mathrm{~W}$ ( $2 \mathrm{wt} \% \mathrm{~W}$ is required to obtain an atomic concentration similar to that for $1 \mathrm{wt} \% \mathrm{Mo}$ ).

Table 3 lists ferritic and martensitic steels for a "first cut" in a FIRD alloy development program. These include the $\mathrm{Cr}-\mathrm{V}, \mathrm{Cr}-\mathrm{W}$, and $\mathrm{Cr}-\mathrm{W}-\mathrm{V}$ steels discussed above. The $9 \mathrm{Cr}-2 \mathrm{~W}-0.25 \mathrm{~V}$ and $12 \mathrm{Cr}-2 \mathrm{~W}-0.25 \mathrm{~V}$ steels are added for comparison with the $9 \mathrm{Cr}-1 \mathrm{MoVNb}$ and $12 \mathrm{Cr}-1 \mathrm{MoVW}$ steels under study in the fusion reactor alloy development program. A suitable substitute for the $0.06 \% \mathrm{Nb}$ in the $9 \mathrm{Cr}-1 \mathrm{MoVNb}$ steel may be $0.12 \% \mathrm{Ta}$ in the $9 \mathrm{Cr}-2 \mathrm{~W}-0.25 \mathrm{~V}$ steel. Tantalum, in the same group of the periodic table as niobium, of ten displays analogous properties to those of niobium. Titanium carbides can also result in dispersion strengthening, and, as discussed below, titanium ad- 
Table 3

Possible ferritic steels for fast induced radioactivity decay alloy development program

\begin{tabular}{lllll}
\hline Alloy & \multicolumn{2}{c}{ Chemical composition ${ }^{2}$ (wt) } & W & C \\
\cline { 2 - 4 } & Cr & V & $0.1-0.15$ \\
\hline $2 \frac{1}{4} \mathrm{Cr}-\frac{1}{4} \mathrm{~V}$ & $2-2.5$ & 0.25 & $0.1-0.15$ \\
$2 \frac{1}{4} \mathrm{Cr}-\frac{1}{2} \mathrm{~V}$ & $2-2.5$ & 0.5 & 2 & $0.1-0.15$ \\
$2 \frac{1}{4} \mathrm{Cr}-2 \mathrm{~W}$ & $2-2.5$ & & 1 & $0.1-0.15$ \\
$2 \frac{1}{4} \mathrm{Cr}-1 \mathrm{~W}-\frac{1}{4} \mathrm{~V}$ & $2-2.5$ & 0.25 & 2 & $0.1-0.15$ \\
$2 \frac{1}{4} \mathrm{Cr}-2 \mathrm{~W}-\frac{1}{4} \mathrm{~V}$ & $2-2.5$ & 0.25 & 2 & $0.1-0.15$ \\
$5 \mathrm{Cr}-2 \mathrm{~W}-\frac{1}{4} \mathrm{~V}$ & 5 & 0.25 & 2 & $0.1-0.15$ \\
$9 \mathrm{Cr}-2 \mathrm{~W}-\frac{1}{4} \mathrm{~V}$ b & 9 & 0.25 & 2 & $0.1-0.15$ \\
$12 \mathrm{Cr}-2 \mathrm{~W}-\frac{1}{4} \mathrm{~V}$ & 12 & 0.2 &
\end{tabular}

a Balance iron.

b An alloy with $0.12 \%$ Ta should be considered to complete the analogy with $9 \mathrm{Cr}-1 \mathrm{MoVNb}$ steel.

ditions may be of interest in later alloys compositions.

The $9 \mathrm{Cr}-1 \mathrm{MoVNb}$ and $12 \mathrm{Cr}-1 \mathrm{MoVW}$ steels were chosen for fusion reactor applications because of their excellent swelling resistance in the breeder reactor program. However, the proposed breeder reactor applications involve service conditions considerably different from those envisioned for fusion reactors. Because of these differences, we previously recommended that $2 \frac{1}{4}$ $\mathrm{Cr}-1$ Mo steel should be strongly considered for fusion reactor applications [4]. ${ }^{*}$ The reasons for this recommendation included the operating temperatures of proposed fusion reactor designs, possible advantages in welding the low-chromium steel, and conservation of a strategic material [4]. The swelling resistance of $2 \frac{1}{4} \mathrm{Cr}-1$ Mo steel was equivalent to that of high-chromium steels when they were compared in ion-irradiation studies [4].

Chromium in excess of about $2.25 \%$ does not affect the elevated-temperature strength, and this amount of chromium provides oxidation resistance adequate for service to about $600^{\circ} \mathrm{C}$ [10]. Chromium content will affect the hardenability, but, for fusion reactor applications, in which relatively thin sections are to be used, this effect should not prove important. One of the reasons why the 9 and $12 \% \mathrm{Cr}$ steels are often assumed to be superior to $2 \frac{1}{4} \mathrm{Cr}-1 \mathrm{Mo}$ steels is that the long-time elevated-temperature strength of the high-chromium $\mathrm{Cr}-\mathrm{Mo}$ steels containing $\mathrm{V}, \mathrm{Nb}$, or $\mathrm{Ti}$ are compared with $2 \frac{1}{4} \mathrm{Cr}-1 \mathrm{Mo}$ without any of these strong carbide formers being added. Whenever the elevated-tempera-

* At present, the alloy development program for fusion reactors calls for about $5 \%$ of the irradiation effects studies to be on $2 \frac{1}{4} \mathrm{Cr}-1 \mathrm{Mo}, 35 \%$ on $9 \mathrm{Cr}-1 \mathrm{MoVNb}$, and $60 \%$ on 12 $\mathrm{Cr}-1 \mathrm{MoVW}$. ture strength of $9 \mathrm{Cr}-1 \mathrm{Mo}$ and $12 \mathrm{Cr}-1 \mathrm{Mo}$ without vanadium or niobium are compared with $2 \frac{1}{4} \mathrm{Cr}-1 \mathrm{Mo}$ (all with similar microstructures), little difference is observed [10]. At higher temperatures, above $600^{\circ} \mathrm{C}$, adequate oxidation resistance will be possible with only the higher chromium steels.

There might well be an advantage for a low-chromium $\mathrm{Cr}-\mathrm{Mo}-\mathrm{V}$ steel, because when the $\mathrm{Cr}-\mathrm{Mo}-\mathrm{V}-\mathrm{C}$ diagrams of Smith [18] are consulted for a 1\% Mo-0.25\% $\mathrm{V}-0.1 \% \mathrm{C}$ steel with $2.25 \% \mathrm{Cr}$ and for the 9 and $12 \mathrm{Cr}$ steels, different carbides are predicted for equilibrium at $700^{\circ} \mathrm{C}$. The $\mathrm{M}_{4} \mathrm{C}_{3}\left(\mathrm{~V}_{4} \mathrm{C}_{3}\right)$ and $\mathrm{M}_{7} \mathrm{C}_{3}$ carbides are present in the $2.25 \% \mathrm{Cr}$ steel, but only $\mathrm{M}_{23} \mathrm{C}_{6}$ is present for the two high-chromium steels. The $\mathrm{M}_{23} \mathrm{C}_{6}$ is generally a coarser carbide than are $M_{4} C_{3}$ and $M_{7} C_{3}$, although, as noted above, vanadium stabilizes a finer precipitate. This possible difference in carbides that occurs with varying chromium concentration does not seem to have been systematically investigated, although the Japanese Steel Works has recently introduced a modified $2 \frac{1}{4}$ $\mathrm{Cr}-1 \mathrm{Mo}$ steel with $0.25 \mathrm{~V}$ and $0.02 \% \mathrm{Ti}$ added [7].

Although the proposed alloy development scheme summarized in table 3 appears to emphasize $2 \frac{1}{4} \mathrm{Cr}$, this is not the case. The low-chromium composition (2.25\%) is used to investigate the effect of vanadium and tungsten. Several alloys with higher chromium are then suggested to determine the effect of chromium. The information thus generated should allow for the determination of the most suitable alloy for any design conditions.

Comparative studies on the $9 \mathrm{Cr}-1 \mathrm{MoVNb}$ and 12 Cr-1 MoVW steels being considered for fusion reactor applications have indicated differences in the long-time elevated-temperature strength, with the $9 \mathrm{Cr}-1 \mathrm{MoVNb}$ 
steel the stronger [20]. This difference may be due to the niobium in the $9 \% \mathrm{Cr}$ steel, because at equilibrium fine $\mathrm{MC}$ carbides in addition to $\mathrm{M}_{23} \mathrm{C}_{6}$ are observed in this steel [10]. Only the $\mathrm{M}_{23} \mathrm{C}_{6}$ is observed in the $12 \mathrm{Cr}-1$ MoVW steel $[10,18,19]$. Although niobium must be eliminated in a FIRD steel, tantalum is of ten analogous to niobium. This is the basis for suggesting a tantalum addition (table 3 ).

As noted above, the Japanese Steel Works added titanium to its modified $2 \frac{1}{4} \mathrm{Cr}_{\mathrm{r}}-1 \mathrm{Mo}$ steel. About $0.02 \%$ $\mathrm{Ti}$ in steels is known to prevent grain coarsening in the weld heat-affected zone during high-heat-input welding, thus assuring good notch toughness. Such titanium additions may be useful in the FIRD alloy development program. There is also evidence that a low-carbon $2 \frac{1}{4}$ $\mathrm{Cr}-1$ Mo steel with about $0.14 \% \mathrm{Ti}$ has creep properties superior to those of commercial $2 \frac{1}{4} \mathrm{Cr}-1$ Mo steel. If the $2 \frac{1}{4} \mathrm{Cr}-2 \mathrm{~W}$ and $2 \frac{1}{4} \mathrm{Cr}-2 \mathrm{~W}-0.25 \% \mathrm{~V}$ steels should have favorable properties, the addition of titanium to one or both of these compositions should be considered.

\subsection{Alloy development strategy}

Any alloy developed for fusion reactor applications must be thoroughly tested in a suitable irradiation environment. However, before detailed irradiation studies are conducted, it is necessary to understand the unirradiated behavior and to compare that behavior with the reference alloys that are currently candidates for fusion reactor applications (i.e., the developmental steel must be compared with $2 \frac{1}{4} \mathrm{Cr}-1 \mathrm{Mo}, 9 \mathrm{Cr}-1 \mathrm{MoVNb}$, and $12 \mathrm{Cr}-1$ MoVW steels). Information will be required on the physical metallurgy (e.g., precipitate type, precipitation kinetics, etc.), fabricability, weldability, elevated-temperature strength, impact properties, compatibility, and other properties. The properties of the FIRD steels must be at least as good as those of commercial $\mathrm{Cr}$-Mo steels. Once alloys with satisfactory unirradiated properties are obtained, detailed irradiation effects studies will be required.

Information on the physical metallurgy of the new steels will come from heat treatment studies to determine the phases developed when quenched, normalized, tempered, and aged. Hardness measurements and optical and electron microscopy will be used to study phase stability. Analysis of carbide extractions may also prove useful.

Fabricability will be determined in the normal melting, casting, and rolling operations necessary to obtain the sheet that will be used to make transmission electron microscopy and mechanical property specimens. A simple weldability test should also be performed; per- haps Varistraint or guide-bend tests could be used for early qualifications.

Elevated-temperature tensile properties of prospective FIRD ferritic steels will be required. Creep properties will also be needed to define upper temperature limits for the alloys. Initially, a comparison of tensile results with the tensile behavior of available steels will provide a relative assessment of the elevated-temperature behavior.

Ferritic steels may be useful only in a temperature window with a lower temperature limit determined by the toughness and impact properties and an upper limit governed by compatibility limits or elevated-temperature strength. The impact properties are affected by irradiation; for example, the ductile-brittle transition temperature of $12 \mathrm{Cr}-1 \mathrm{MoVW}$ steel increased by $108^{\circ} \mathrm{C}$ during irradiation in EBR-II at $419^{\circ} \mathrm{C}$ to $1.1 \times 10^{26}$ $\mathrm{n} / \mathrm{m}^{2}$ [21] accompanied by a decrease in the upper-shelf energy. Any FIRD alloy development program must consider the impact properties of the proposed alloys. These properties must be at least as good as those of present candidate ferritic steels.

Finally, it will be necessary to determine the compatibility of these steels with potential coolant and breeding materials (i.e., water, helium, lithium, lead-lithium alloys, and solid lithium ceramics). Because there is no change in chromium concentration between these steels and the $\mathrm{Cr}$-Mo steels, little difference in compatibility is expected. Nevertheless, comparative tests will be necessary.

\section{Summary}

It appears to be possible to develop $\mathrm{Cr}$-Mo steels that have relatively fast induced-radioactivity decay (FIRD) characteristics, which would simplify the radioactive waste disposal problem for first wall and blanket structures of fusion reactors after shutdown. An approach to developing such steels has been presented.

For steels with properties analogous to the $\mathrm{Cr}-\mathrm{Mo}$ steels, the substitution of tungsten for molybdenum appears to be straightforward. To induce dispersion strengthening, the addition of vanadium is possible; titanium and tantalum additions may also be valuable.

\section{Acknowledgments}

We gratefully acknowledge several people who aided in this work. Detailed discussions with F.W. Wiffen were invaluable. The manuscript was reviewed by V.K. 
Sikka and F.W. Wiffen. Irene Brogden edited the manuscript and Frances Scarboro prepared the manuscript.

\section{References}

[1] R.W. Conn et al., Panel report on low activation materials for fusion applications, UCLA Report PPG-728, University of California at Los Angeles, June 1983; also published as: Low activation materials and magnetic fusion reactors, Nucl. Technol./Fusion 5 (1984) 241.

[2] Nuclear Regulatory Commission, Licensing Requirements for Land Disposal of Radioactive Waste, 10 CFR Part 61, Fed. Regist. 47 (248) 57446-82 (Dec. 27, 1982).

[3] R.L. Klueh and E.E. Bloom, the development of austenitic steels for fast induced-radioactivity decay for fusion reactor applications, to be published.

[4] R.L. Klueh, Chromium-molybdenum steels for fusion reactor first walls - a review, Nucl. Engrg. Des. 72 (1982) 329-344.

[5] K.J. Irvine, J.D. Murray and F.B. Pickering. Structural aspects of creep-resisting steel, in: Structural Processes in Creep (Iron and Steel Institute, London, 1961) pp. 246-275.

[6] R.G. Baker and J. Nutting, The tempering of $2 \frac{1}{4} \mathrm{Cr}-1 \mathrm{Mo}$ steel after quenching and normalizing. J. Iron Steel Inst., London 192 (1959) 257-268.

[7] $\mathrm{T}$. Ishiguro et al., A $2 \frac{1}{4} \mathrm{Cr}-1 \mathrm{Mo}$ pressure vessel steel with improved creep rupture strength, in: Application of 2! Cr-1 Mo Steel for Thick-Wall Pressure Vessels. ASTM STP 755, eds. G.S. Sangdahl and M. Semchyshen (American Society for Testing and Materials. Philadelphia, 1982) pp. 129-147.

[8] S.N. Rosenwasser et al., The application of martensitic steels in long lifetime fusion first wall/blankets, J. Nucl. Mater. 85 \& 86 (1979) 177-182.

[9] S.D. Harkness and B. Cramer, A review of lifetime analyses for tokamaks, J. Nucl. Mater. 85 \& 86 (1979) 135-145.

[10] J. Orr, F.R. Beckitt and G.D. Fawkes, The physical metallurgy of chromium-molybdenum steels for fast reactor boilers, in: Ferritic Steels for Fast Reactor Steam Genera- tors (British Nuclear Energy Society. London. 1978) vol. 1. pp. 91-109.

[11] J.M. Vitek and R.L. Klueh, Precipitation reactions during the heat treatment of ferritic steels, Metall. Trans: 14A (1983) 1047-1055.

[12] L. Egnell and N.G. Persson. On the creep properties of Sandvik HT7 and HT9, in: Ferritic Steels for Fast Reactor Steam Generators (British Nuclear Energy Society. London, 1978) Vol. 1, pp. 212-216.

[13] G. Oakes, J. Orr and P.W. Taylor, The effect of tungsten on the tensile and creep rupture strength of $12 \mathrm{CrMoV}$ steels, in: Ferritic Steels for Fast Reactor Steam Generators (British Nuclear Energy Society, London, 1978) Vol. 1. pp. 222-227.

[14] N.M. Ghoniem, A. Shabiak and M.Z. Youssef. Development of a "low-activation" vanadium steel for fusion applications, in: Ferritic Alloys for Use in Nuclear Energy Technologies (The Metallurgical Society of AIME. NewYork, 1984) pp. 201-208.

[15] A.D. Batte and R.W.K. Honeycombe, Precipitation of vanadium carbide in ferrite, J. Iron Steel Inst., London 211 (1973) 284-295.

[16] R.W.K. Honeycombe. Structure and Strength of Alloy Steels (Climax Molybdenum Company, London, 1974).

[17] P.W. Wilyman and R.W.K. Honeycombe, Relation between $\gamma-\alpha$ transformation kinetics and mechanical properties of vanadium steels, Met. Sci. 16 (1982) 295-303.

[18] R. Smith, Fe-Cr-Mo-V constitution diagrams, in: Precipitation Processes in Steels. Special Report 64 (Iron and Steel Institute, London, 1959) pp. 307-311.

[19] K.W. Andrews, H. Hughes and D.J. Dyson, Constitution diagrams for Cr-Mo-V Steels. J. Iron Steel Inst., London 210 (1972) 337-350.

[20] V.K. Sikka, C.T. Ward and K.C. Thomas, Modified 9 $\mathrm{Cr}-1$ Mo steel - an improved alloy for steam generator application, in: Ferritic Steels for High-Temperature Applications (American Society for Metals, Metals Park. Ohio, 1983) pp. 65-84.

[21] F.A. Smidt, J.R. Hawthorne and V. Provenzano, Fracture resistance on HT- 9 after irradiation at elevated temperature, in: Effects of Irradiation on Materials. ASTM STP 725 (American Society for Testing and Materials. Philadelphia, 1981) pp. 269-284. 